\title{
Cytotoxicity of polycations: Relationship of molecular weight and the hydrolytic theory of the mechanism of toxicity
}

Citation for published version (APA):

Cavill, R., \& Thanou, M. (2017). Cytotoxicity of polycations: Relationship of molecular weight and the hydrolytic theory of the mechanism of toxicity. International Journal of Pharmaceutics, 521(1-2), $249-258$. https://doi.org/10.1016/j.ijpharm.2017.02.048

Document status and date:

Published: 15/04/2017

DOI:

10.1016/j.ijpharm.2017.02.048

Document Version:

Publisher's PDF, also known as Version of record

\section{Document license:}

Taverne

Please check the document version of this publication:

- A submitted manuscript is the version of the article upon submission and before peer-review. There can be important differences between the submitted version and the official published version of record.

People interested in the research are advised to contact the author for the final version of the publication, or visit the DOI to the publisher's website.

- The final author version and the galley proof are versions of the publication after peer review.

- The final published version features the final layout of the paper including the volume, issue and page numbers.

Link to publication

\footnotetext{
General rights rights.

- You may freely distribute the URL identifying the publication in the public portal. please follow below link for the End User Agreement:

www.umlib.nl/taverne-license

Take down policy

If you believe that this document breaches copyright please contact us at:

repository@maastrichtuniversity.nl

providing details and we will investigate your claim.
}

Copyright and moral rights for the publications made accessible in the public portal are retained by the authors and/or other copyright owners and it is a condition of accessing publications that users recognise and abide by the legal requirements associated with these

- Users may download and print one copy of any publication from the public portal for the purpose of private study or research.

- You may not further distribute the material or use it for any profit-making activity or commercial gain

If the publication is distributed under the terms of Article $25 \mathrm{fa}$ of the Dutch Copyright Act, indicated by the "Taverne" license above, 


\title{
Cytotoxicity of polycations: Relationship of molecular weight and the hydrolytic theory of the mechanism of toxicity
}

\author{
Bryn D. Monnery ${ }^{\mathrm{a}, 1}$, Michael Wright ${ }^{\mathrm{b}}$, Rachel Cavill ${ }^{\mathrm{c}}$, Richard Hoogenboom ${ }^{\mathrm{d}}$, \\ Sunil Shaunak ${ }^{\mathrm{e}}$, Joachim H.G. Steinke ${ }^{\mathrm{a}, 2}$, Maya Thanou ${ }^{\mathrm{b}, *}$ \\ ${ }^{a}$ Chemical Biology Section, Department of Chemistry, Imperial College London, London SW7 2AZ, UK \\ b Institute of Pharmaceutical Science, King's College London,Franklin-Wilkins Building, London, SE1 9NH, UK \\ ${ }^{\mathrm{c}}$ Department of Data Science and Knowledge Engineering, Maastricht University, P.O. Box 616, 6200 MD, Maastricht, The Netherlands \\ d Department of Organic and Macromolecular Chemistry, Ghent University, Krijgslaan 281-S4, 9000 Gent, Belgium \\ e Department of Infectious Diseases and Immunity, Faculty of Medicine, Imperial College London, Hammersmith Campus, London, W12 ONN, UK
}

\section{A R T I C L E I N F O}

\section{Article history:}

Received 29 November 2016

Received in revised form 13 February 2017

Accepted 18 February 2017

Available online 21 February 2017

\section{Keywords:}

Cytotoxicity

Gene therapy

Hydrolysis

Molecular weight

MTT assay

Phospholipids

\begin{abstract}
A B S T R A C T
The mechanism of polycation cytotoxicity and the relationship to polymer molecular weight is poorly understood. To gain an insight into this important phenomenon a range of newly synthesised uniform (near monodisperse) linear polyethylenimines, commercially available poly(L-lysine)s and two commonly used PEI-based transfectants (broad $22 \mathrm{kDa}$ linear and $25 \mathrm{kDa}$ branched) were tested for their cytotoxicity against the A549 human lung carcinoma cell line. Cell membrane damage assays (LDH release) and cell viability assays (MTT) showed a strong relationship to dose and polymer molecular weight, and increasing incubation times revealed that even supposedly "non-toxic" low molecular weight polymers still damage cell membranes. The newly proposed mechanism of cell membrane damage is acid catalysed hydrolysis of lipidic phosphoester bonds, which was supported by observations of the hydrolysis of DOPC liposomes.
\end{abstract}

Crown Copyright (c) 2017 Published by Elsevier B.V. All rights reserved.

\section{Introduction}

Polycations are materials that find application as delivery vectors in the field of DNA and RNA based therapies, because they condense polyanionic nucleic acids. This is a field with enormous promise, but one that has failed to achieve its full potential despite great clinical interest; mostly due to the toxicity of the polycationic carriers. (Behr, 2012; Gary et al., 2007; Pack et al., 2005) Further problems arise due to the fact that polymeric transfection methods require a large excess of polycations, which is not associated with the poly(nucleic acid), (Boeckle et al., 2004; Dai et al., 2011; Yue et al., 2011) and this present major limitations on in-vivo transfection due to different trafficking of the two populations.

Polyethylenimine (PEI) is a cationic polymer which is commonly available with branched and linear structures, and has been synthesised in hairy, comb and cyclic structures. The branched

\footnotetext{
* Corresponding author.

E-mail address: Maya.thanou@kcl.ac.uk (M. Thanou).

1 Present address; Department of Organic and Macromolecular Chemistry, Ghent University, Krijgslaan 281S-4, 9000 Gent, Belgium.

2 Author is deceased.
}

structure is synthesised via the aqueous cationic polymerisation of aziridines, whilst the linear form is typically synthesised by the hydrolysis of a poly(2-oxazoline). (Monnery and Hoogenboom, 2015) Poly(L-lysine) is also commonly available via the ringopening polymerisation of $\mathrm{N}$-carbobenzoxy-L-lysine- $N$-carboxy anhydride. (Fasman et al., 1961) Since these polycations are some of the most frequently used in cell transfection, this work concentrates on assaying these materials.

The mechanism of cytotoxicity of polycationic materials, such as PEI, is a poorly understood matter. (Parhamifar et al., 2010) It is known that polycationic materials do not produce an apoptotic response, but rather cell death is due to necrosis, (Fischer et al., 2003 ) and that a variety of organelles are damaged. (Grandinetti et al., 2011; Grandinetti et al., 2012; Moghimi et al., 2005) The mechanism of the necrotic damage is not yet understood. Here we aim to investigate the effect of the properties of the polymer on cell membrane damage.

There is a significant body of evidence that polycations open pores in cellular membranes. Banaszak-Holl and coworkers have shown that a wide variety of cationic macromolecules open pores in a supported phospholipid bilayers. (Hong et al., 2004; Hong et al., 2006; Leroueil et al., 2008; Mecke et al., 2005) Poration of the cells is a common way of transfecting cells, with various physical 
methods (electroporation etc.) and chemicals such as surfactants allowing polynucleic acids to simply diffuse into the cells. (Hapala, 1997) However, commonly used polycations such as PEI and PLL should not act as surfactants.

It has been shown that the presence of uncomplexed polycation is responsible for the cell damage, but without their presence there is limited transfection. (Boeckle et al., 2004; Fahrmeir et al., 2007; Hanzlikova et al., 2011; Yue et al., 2011)Kichler et al. reported that PEI has no effect on cell membranes. (Kichler et al., 2001) However, the underlying experiments were carried out in citrate buffer, and the PEI was hence sequestered into an uncharged PEI-citrate complex(Eberhardy et al., 2009), so no free polymer was present.

The effect of cationic polymer molecular weight on the cytotoxicity is poorly understood. Fischer et al. claim that higher molecular weight materials are more toxic, (Fischer et al., 2003) but this is based on a rather random selection of cationic polymers as only one molecular weight of a range of different polymers is assayed and compared. Long et al. performed a systematic survey of the toxicity of poly( $N, N$-dimethylaminoethyl methacylate $)$, but unfortunately the lowest molecular weight assayed (43 kDa) was so toxic that no relationship can be discerned, although toxicity was clearly due to membrane lysis. (Layman et al., 2009) Two groups (Coll et al. and Wurm et al.) have independently fractionated a commercial broadly-polydisperse linear PEI (l-PEI) and assayed the individual fractions for transfection efficacy. They both reported that fractions below $4 \mathrm{kDa}$ show little transfection activity and little toxicity, and fractions above $20 \mathrm{kDa}$ show little activity but high toxicity, with a maximum transfection efficiency at ca. 15 kDa. (Falco et al., 2009; Kadlecova et al., 2012) However, neither group performed an LDH or similar assay to assess the effect of the molecular weight on cell membrane disruption. Boe et al. assayed a limited range of commercial PEI samples of both linear and branched structures on osteosarcoma cells, with mitochondrial activity measured by (3-(4,5-dimethylthiazol-2yl)-5-(3-carboxymethoxyphenyl)-2-(4-sulfophenyl)-2H-tetrazoli$\mathrm{um}$ ) (MTS) after $24 \mathrm{~h}$ exposure. However, the limited range of materials (i.e. no polycations between 2.5 and $25 \mathrm{kDa}$ ) and lack of LDH or similar assays make further interpretation difficult (Boe et al., 2008). In none of these cases the degree of cell membrane disruption has been assessed (i.e. by the lactose dehydrogenase assay), and since the toxicity is clearly due to the disruption and poration of cellular membranes this is clearly a major gap in our knowledge, which will be addressed in the current work.

The mechanism by which polycations induce pores on cellular membranes remains obscure, and essentially two reasonable models exist: either the polycations act as a surfactant(Vaidyanathan et al., 2016) or as a proton transfer catalyst. (Seddon et al., 2009) In the latter, the polycations acts as a proton transfer catalyst that could lead to the hydrolysis of the phospholipids and changes in the curved elastic stress of the membrane. This induces the formation of inverted hexagonal phases in the lipid bilayer ("pores") and phase separation of lysophospholipids which form blebs, this being demonstrated for low molecular weight cationic materials. (Baciu et al., 2006; Casey et al., 2014; Casey, 2011; Shearman et al., 2007) The latter requires the cationic polymer to stabilise a pore, and thus remain localised in the pore. This has never been observed, although the surfactant effect may explain poration by amine functionalized silica or gold nanoparticles, which has been observed by Banaszak-Holl and coworkers.

The hypothesis of this work is that the toxicity of polycations increases with molecular weight (assuming the same structure and architecture), and is due to a greater degree of membrane disruption. To test this a systematical series of 1-PEI covering a broad molar mass range has been synthesised (Monnery et al., 2015) and tested for mitochondrial activity and cell membrane damage in the A549 cell line, in comparison to $25 \mathrm{kDa}$ hyperbranched PEI (b-PEI) and a series of poly(L-lysine)s (PLL). To address the postulated membrane disruption by either hydrolysis or surfactant mechanism, experiments were undertaken to evaluate the hydrolysis of 1,2-dioleoyl-sn-glycero-3-phosphocholine (DOPC) in presence of PEI by HPLC.

\section{Materials and methods}

\subsection{Materials}

Calcium hydride (93\%), 2-ethyl-2-oxazoline (99\%), methyl tosylate (98\%), dimethyl sulfoxide (99\%), thiazolyl blue tetrazolium bromide (98\%), various poly(L-lysine)s, 1,2-dioleoyl-sn-glycero-3phosphocholine, various poly-L-lysines and $25 \mathrm{kDa}$ hyperbranched PEI were purchased from Sigma-Aldrich. Water used was purified by reverse osmosis to $18 \mathrm{M} \Omega$ (Barnstead Nano-pure). Hydrochloric acid (37\%), sodium hydroxide (99\%+, pellets), DCM $(99.8 \%+)$ and diethyl ether $(99.8 \%+)$ were purchased from VWR (Lutterworth, UK). Phosphate buffered saline, DMEM (Glutamax), OptiMEM and fetal calf serum were purchased from Gibco (Thermo Fisher Scientific Inc., Loughborough, U.K.). LDH release assay were purchased from Promega (Madison, WI, U.S.A.) under the name "CytoTox 96 ${ }^{\circledR}$ Non-Radioactive Cytotoxicity Assay".

Acetonitrile was stirred over calcium hydride overnight and then refluxed $(2 \mathrm{~h})$ before being distilled under argon into a Schlenk equipped two necked round bottom flask. 2-Ethyl-2oxazoline was stirred over calcium hydride overnight and then refluxed $(2 \mathrm{~h}$ ) before being distilled onto activated $3 \AA$ molecular sieves (activated by heating $>300^{\circ} \mathrm{C}$ for $>1 \mathrm{~h}$ under $<1 \mathrm{mbar}$ vacuum, cooling and backfilling with dry nitrogen). Nitrogen gas (BOC) and argon (BOC pureshield) were dried through sodium hydroxide and self-indicating silica gel. Syringe filters $(0.22 \mu \mathrm{m}$ polysulfonate filter with polypropylene housing) were purchased from Fisher (Loughborough, UK).

Standard glassware was used throughout. The polymerisation vessel was an oven dried two neck flask equipped with a tap (for addition of liquid reagents and sampling) and a condenser with an isolation tap connected to the Schlenk line via rubber tubing and was flame dried under vacuum before use. Liquid reagents were handled with vacuum dried gas-tight syringes (Hamilton, Bonaduz, Switzerland) using Schlenk technique. Glassware for hydrolysis to l-PEI etc. was similar, although less rigorous procedures were adopted in light of the aqueous solvent.

\subsection{Instrumentation and polymer characterisation}

Polymers were analysed by Size Exclusion Chromatography (SEC) and Nuclear Magnetic Resonance Spectroscopy (NMR). The SEC was a Polymer Laboratories GPC-50 with $2 \times$ PLGEL MIXED-D $(300 \times 75 \mathrm{~mm})$ columns and a guard column $(50 \times 7.5 \mathrm{~mm}$ MIXEDD), using DMF (1\% (v/v) triethylamine and acetic acid); poly(methyl methacrylate) (PMMA) standards were used as calibrants. A sample of the crude reaction mixture was mixed with an equal volume of deuterated chloroform and analysed via ${ }^{1} \mathrm{H}$ NMR spectroscopy on a Bruker DX-400 machine and the degree of conversion was determined by integrating the polymer backbone $(\delta=3.1-3.8 \mathrm{ppm})$ and the two methylene peaks ( 4 and 5 position) of the oxazoline ring ( $\delta \sim 3.8$ and 4.1 ) using the equation:

$$
p=\frac{\sum \delta(\text { backbone })}{\sum\left(\delta(\text { backbone })+\delta\left(\text { monomer } 4^{\prime}\right)+\delta\left(\text { monomer }^{\prime}\right)\right)}
$$

A multi-angle light scattering DAWN EOS (Wyatt Technologies Corporation) was placed in series between the SEC column and the refraction index detector and used to determine $\bigoplus_{\mathrm{LS}}$. (Shortt, 1994) 
Microplates were read on a Spectra Max 190 microplate reader (Molecular Devices, Sunnyvale, California) at the appropriate wavelength. Cell images were obtained with a Zeiss Vision KS400 system (Carl Zeiss, Gottingen, Germany). High-Performance Liquid Chromatography (HPLC) eluograms were recorded on an Agilent 1100 series with quaternary pump, diode array detector, evaporative light scattering detector (Polymer Labs PL-ELS 2100) and an incubated injector. The column was a $5 \mathrm{~cm} 5 \mu \mathrm{m}$ C18 (Phenomenex, Macclesfield, U.K.) with the elution gradient 0 min water, $11 \mathrm{~min}$ acetonitrile, $12 \mathrm{~min}$ acetonitrile, $23 \mathrm{~min}$ methanol, $25 \mathrm{~min}$ methanol, $27 \mathrm{~min}$ water, $30 \mathrm{~min}$ water. All solvent changes were isocratic. Flow rate was $2.5 \mathrm{~mL} / \mathrm{min}$.

\subsection{Synthesis of poly(2-isopropyl-2-oxazoline) and hydrolysis to l-PEI}

The synthesis of these materials has been reported. (Monnery et al., 2015)

\subsection{Polymerisation of EtOx500}

The polymerisation was carried out essentially as per the commercial product in-vivo jetPEI. (Adib et al., 2010) Into a two neck round bottom flask with stirrer and reflux condenser was added 2-ethyl-2-oxazoline ( $5 \mathrm{~mL}, 4.75 \mathrm{~g}, 4.8 \mathrm{mmol}$ ), dry acetonitrile and a methyl tosylate stock solution in acetonitrile for a monomer to initiator (M:I) ratio of 500 (17.85 mg MeOTs, $95.8 \mu \mathrm{mols}$ in $10 \mathrm{~mL}$ acetonitrile). The mixture was refluxed under argon for $48 \mathrm{~h}$, with a sample taken at $24 \mathrm{~h}\left(90 \%\right.$ conversion by ${ }^{1} \mathrm{H}$ NMR spectroscopy) and quenched at $48 \mathrm{~h}$ (99.5\% conversion) with a $5 \%$ sodium carbonate in water solution and left to reflux overnight before being extracted into dichloromethane. The organic phase was dried with anhydrous magnesium sulfate, filtered through paper and concentrated in vacuo before precipitating into 20 vols of diethyl ether, filtering (P2 glass frit) and drying in vacuo yielded a slightly yellow powder E1 (4.2 g, 90\%). The ${ }^{1} \mathrm{H}$ NMR spectrum was consistent with the literature. (Rivas and Ananías, 1987)

${ }^{1} \mathrm{H}$ NMR (400 MHz, $\left.\mathrm{D}_{2} \mathrm{O}\right) \delta=1.00$ (br, $3 \mathrm{H}, \mathrm{CH}_{2}-\mathrm{CH}_{3}$ ), 2.30 (br, $2 \mathrm{H}$, $\left.(\mathrm{C}=\mathrm{O})-\mathrm{CH}_{2}-\mathrm{CH}_{3}\right), 3.46+3.54\left(2 \mathrm{x}\right.$ br, $\left.4 \mathrm{H}, \mathrm{C}(\mathrm{C}=\mathrm{O})-\mathrm{CH}_{2}-\mathrm{CH}_{2^{-}}\right)$

SEC: $\mathrm{M}_{\mathrm{n}}=24.4 \mathrm{kDa}, \mathrm{M}_{\mathrm{m}}=49.8 \mathrm{kDa}, \mathrm{M}_{\mathrm{p}}=61.8 \mathrm{kDa}, \bigoplus_{\mathrm{RI}}=2.04, \bigoplus_{\mathrm{MALS}}=$ 1.12

\subsection{Hydrolysis to l-PEI500}

$\mathrm{P}(\text { EtOx })_{500}(1.40 \mathrm{~g}, 14 \mathrm{mmol}$ of repeat units) was dissolved in $6 \mathrm{~N}$ hydrochloric acid $(50 \mathrm{~mL})$ and refluxed overnight at $120^{\circ} \mathrm{C}$ in an oil bath. The volatiles were removed in vacuo, the residue was dissolved in boiling water $(50 \mathrm{~mL})$ and made basic with sodium hydroxide ( $\sim 1 \mathrm{~g})$. On cooling the hydrate of L-PEI precipitated, was filtered (P2 glass frit), washed with water $(\sim 1 \mathrm{~L})$ until the filtrate was neutral and dried in vacuo overnight to yield a white powder. A sample (43.5 mg, $1 \mathrm{mmol}$ ) was placed in a HPLC vial and dissolved in propanoic anhydride $(0.64 \mathrm{~mL}, 5 \mathrm{mmol}, 5$ equiv), sealed and heated to $65^{\circ} \mathrm{C}$ overnight, cooled, quenched with water $(1 \mathrm{~mL})$ and the volatiles removed. The residue was analysed by SEC and showed no significant change in molecular weight distribution compared to the starting polymer, showing main chain stability during hydrolysis. The remainder of the product was dissolved in boiling water $(1 \mathrm{~mL})$ and $37 \%$ hydrochloric acid $(1 \mathrm{~mL})$ was added. The volatiles were removed in vacuo to yield PEI500 as a white powder $(0.97 \mathrm{~g}, 86 \%)$. The ${ }^{1} \mathrm{H}$ NMR spectrum was consistent with the literature and showed 99.6\% hydrolysis. (Adib et al., 2010; Saegusa et al., 1972)

${ }^{1} \mathrm{H}$ NMR (400 MHz, $\mathrm{D}_{2} \mathrm{O}$ ): $\delta=3.5$ (br, $4 \mathrm{H},-\mathrm{CH}_{2}-\mathrm{CH}_{2}-\mathrm{NH}_{2} \mathrm{Cl}-$ )

${ }^{13} \mathrm{C}$ NMR (101 MHz, $\left.\mathrm{D}_{2} \mathrm{O}\right): \delta=44.0\left(-\mathrm{CH}_{2}-\mathrm{CH}_{2}-\mathrm{NH}_{2} \mathrm{Cl}-\right)$

\subsection{Branched PEI hydrochloride}

Freebase hyperbranched PEI $(0.64 \mathrm{~g})$ was dissolved in $6 \mathrm{~N}$ hydrochloric acid $(25 \mathrm{~mL})$ and stirred for $1 \mathrm{~h}$. Volatiles were removed in vacuo to yield $1.12 \mathrm{~g} \mathrm{(100 \% )}$ of slightly yellow crystals.

${ }^{1} \mathrm{H}$ NMR (400 MHz, $\mathrm{D}_{2} \mathrm{O}$ ): $\delta=2.7-3.9$ (br m, $4 \mathrm{H},-\mathrm{CH}_{2}-\mathrm{CH}_{2}-$ $\mathrm{NH}_{2} \mathrm{Cl}$-), 7.4-8.3 (br m, various amines),

${ }^{13} \mathrm{C}$ NMR (101 MHz, $\mathrm{D}_{2} \mathrm{O}$ ): $\delta=35.5$ (methylene adjacent to $1^{\circ}$ amine in $1^{\circ}-3^{\circ}$ diad), 37.0 (methylene adjacent to $1^{\circ}$ amine in $1^{\circ}-2^{\circ}$ diad), 43.5 (methylene adjacent to $2^{\circ}$ amine in $2^{\circ}-3^{\circ}$ diad), 44.5 (methylenes inside $2^{\circ}-2^{\circ}$ diad), 46.5 (methylene adjacent to $2^{\circ}$ amine in $1^{\circ}-2^{\circ}$ diad), 49.0 (methylene adjacent to $3^{\circ}$ amine in $2^{\circ}-$ $3^{\circ}$ diad), 50.0 (methylene adjacent to $3^{\circ}$ amine in $1^{\circ}-3^{\circ}$ diad)

\subsection{Investigation in the effect of molecular weight on cell membrane viability}

A549 cells (European Collection of Cell Cultures) were cultured in supplemented DMEM (10\% v/v FCS, 1\% 5000 units/mL Penicillin/ 5000 units/mL Streptomycin). Subculturing and the preparation of plates are described in the supplementary information.

Polycation stock solutions were made at $1 \mathrm{mg} / \mathrm{mL}$ in serum free OptiMEM $(\sim 25 \mathrm{~mL})$ and filter sterilised $(0.22 \mu \mathrm{m}$ polysulfonate syringe filter), discarding the first $5 \mathrm{~mL}$ of filtrate (to remove filter adsorption effects). After equilibrating at room temperature for at least $24 \mathrm{~h}$ (to stabilise $\mathrm{pH}$ ) serial dilutions were made with OptiMEM for final polycations concentrations of $1000 \mu \mathrm{g} / \mathrm{mL}$, $100 \mu \mathrm{g} / \mathrm{mL}, 10 \mu \mathrm{g} / \mathrm{mL}$ and $1 \mu \mathrm{g} / \mathrm{mL}$. The media in the experimental wells was carefully removed by hypodermic syringe and replaced with $100 \mu \mathrm{L}$ of serum free OptiMEM. Once all wells had undergone the media change the process was repeated, adding the appropriate polycation solution. Wells were left for negative control (no cells), negative control (lysed cells), positive control (no polycation, vehicle control) and dilution control (no cells, but lysis buffer added). The plates were then returned to the incubator. One $h$ before experimental readout $10 \mu \mathrm{L}$ of Lactate Dehydrogenase (LDH) lysis buffer (1.1\% triton $\mathrm{x}-100)$ was added to the positive control and dilution control wells. This plate is designed plate A.

The procedure for LDH/MTT experiments was thus; after the required incubation time (generally $4 \mathrm{~h}$ ) the supernatant was carefully removed from each well of plate A with a multichannel pipette set at $150 \mu \mathrm{L}$ and transferred to a 96 well v-bottom plate (plate B). The media of plate A was replaced with $100 \mu \mathrm{L}$ complete media, $20 \mu \mathrm{L}$ of MTT solution (5 mg/mL 3-(4,5-dimethylthiazol-2yl)-2,5-diphenyltetrazolium bromide in PBS) was added and the plate returned to the incubator for $5 \mathrm{~h}$. Plate B was sealed with parafilm and centrifuged (241g, $4 \mathrm{~min}$ ), then $50 \mu \mathrm{L}$ of the supernatant was transferred to a 96 well flat bottom plate (plate C). $50 \mu \mathrm{L}$ of reconstituted $\mathrm{LDH}$ was added to all wells and the plate wrapped in aluminium foil and placed in the dark. After exactly $30 \mathrm{~min} 50 \mu \mathrm{L}$ stop solution ( $1 \mathrm{M}$ acetic acid) was added to each well. The absorbance at $490 \mathrm{~nm}$ was read on an ELISA plate reader. Excess LDH release was calculated from plate B as follows:

$L D H$ Release $=\frac{A_{490}(\text { experimental })-A_{490}(\text { negative })}{A_{490}(\text { positive })-A_{490}(\text { negative })}$ 
Where $\mathrm{A}_{490}=$ absorbance at $490 \mathrm{~nm}$, (experimental) is the observed result, (negative) is the average result of 6 vehicle control wells, and (positive) is the average result of 6 control wells lysed with $1.1 \%$ Triton $X-1001 \mathrm{~h}$ prior to the addition of the assay reagent.

For MTT plate A was centrifuged ( $241 \mathrm{~g}, 4 \mathrm{~min})$, the supernatant removed carefully, DMSO $(100 \mu \mathrm{L})$ was added and the plate returned to the incubator. After $30 \mathrm{~min}$ the absorbance at $570 \mathrm{~nm}$ read on an ELISA plate reader. Viability was calculated from plate $A$ as follows:

Mitochondrial Activity $=\frac{A_{570}(\text { experimental })-A_{570}(\text { negative })}{A_{570}(\text { positive })-A_{570}(\text { negative })}$

Where absorbance values are analogous to those in the LDH assay.

Some MTT assays were conducted without LDH, and were performed as above without the LDH component.

$\mathrm{IC}_{20}$ and $\mathrm{IC}_{50}$ values were computed by fitting a linear model to the measurements and the logged doses for each polymer at each time-point. This linear model was used to predict the doses needed to get $50 \%$ and $20 \%$ toxicity, along with the $95 \%$ upper and lower bounds for these values determined using the LINEST function of Microsoft Excel to determine $\Delta \mathrm{y}$.

\subsection{Studies of phospholipid hydrolysis}

DOPC liposomes were formed by placing $200 \mu \mathrm{L}$ of a $10 \mathrm{mg} / \mathrm{mL}$ DOPC in chloroform solution into a $5 \mathrm{~mL}$ round bottom flask, and removing the volatiles in vacuo. The DOPC was re-suspended in water and sonicated for $1 \mathrm{~h}$ at $40^{\circ} \mathrm{C}$ to yield liposomes. To $0.5 \mathrm{~mL}$ of a $2 \mathrm{mg} / \mathrm{mL}$ DOPC liposome suspension as added $0.5 \mathrm{~mL}$ of $2 \mathrm{mg} / \mathrm{mL}$ PEI358 (both in water and prewarmed to $37^{\circ} \mathrm{C}$ ). The mixture was incubated at $37^{\circ} \mathrm{C}$ in a temperature controlled HPLC sample chamber and samples were taken every $32 \mathrm{~min}$ ( or $4 \mathrm{~h}$ ) by the HPLC autosampler.

\section{Results and discussion}

\subsection{Selection and synthesis of polymeric materials}

\subsubsection{Synthesis and characterisation of l-PEI}

The PEI500 sample was synthesised as per an existing patent (Adib et al., 2010), so as to give a material comparable with the commercial material. It was of interest whether the fairly broad molecular weight distribution observed for the precursor poly(2ethyl-2-oxazoline) would be preserved in the synthesised l-PEI. Hence re-acylation of the PEI freebase was conducted, and the molecular weight distribution was indeed preserved (see Fig. S1), which was consistent with a recent report. (de la Rosa et al., 2014) This is at odds with the usually proposed mechanism of chain transfer, which postulates that branch points will be hydrolysed. (Litt et al., 1975; Warakomski and Thill, 1990)

Broad 1-PEI500 was synthesised by hydrolysis in $16.5 \%(\mathrm{v} / \mathrm{v})$ hydrochloric acid (degree of hydrolysis (99.6\%), the volatiles removed, re-dissolved in boiling water (ca. $5 \mathrm{~mL}$ ) and made basic with $\mathrm{NaOH}$. The freebase PEI crystallised as the temperature fell below $\sim 60^{\circ} \mathrm{C}$ and the PEI was washed with copious water until the filtrate was neutral. (Lambermont-Thijs et al., 2009) Each freebase PEI was converted back into the hydrochloride salt by dissolving in $1 \mathrm{~mL}$ of boiling water followed by the addition of $1 \mathrm{~mL}$ conc. hydrochloric acid, and followed by the removal in vacuo of volatiles.

The dispersity value reported in the patent literature was obtained via multi-angle light scattering. The SEC system employed here was equipped with such a device, and the observed $\bigoplus_{\text {MALS }}$ was 1.12 (see Fig. S2), which is comparable to the commercial material. (Adib et al., 2010; Shortt, 1994)

The synthesis of the five narrow l-PEI polymers has been previously described. (Monnery et al., 2015)

\subsubsection{Comparator polycations}

Comparisons between different polycations are complicated by the fact that the common nomenclature used for PEI and PLL are different. PEI molecular weights are reported as the freebase (despite the linear form being invariably used as a hydrochloride salt), whilst PLL molecular weights are reported including the counter-ion (invariably a hydrogen bromide salt). For this reason in this paper we have decided to refer to the polymers by their $\mathrm{DP}_{\mathrm{w}}$, thereby avoiding this confusion.

Branched $25 \mathrm{kDa}$ PEI (b-PEI) and a range of commercially available PLL with similar molecular weights and were also chosen as comparators. The b-PEI was chosen due to its common use in gene therapy studies, and hydrochloride salt as well as the freebase was investigated. The PLL was chosen as a commonly used transfectant available in a range of molecular weights. However due to the different $\mathrm{pK}_{\mathrm{a}}$ values, the protonation states of the polymers will be different.

The $\mathrm{pK}_{\mathrm{a}}$ of linear PEI is 7.2-7.9 (Brissault et al., 2003). For branched PEI von Harpe et al. have measured the $25 \mathrm{kDa}$ branched PEI itself and report a $\mathrm{pK}_{\mathrm{a}}$ of 8.4. (Suh et al., 1994; von Harpe et al., 2000) The $\mathrm{pK}_{\mathrm{a}}$ of PLL is that of lysine (10.5) and the $\mathrm{pK}_{\mathrm{a}}$ is not dispersed, unlike PEI. (Frey and Corn, 1996) This means that using the Henderson-Hasselbalch equation it can be determined that at $\mathrm{pH}=7.4$ approximately $55 \%$ of linear PEI secondary amines are protonated, $\sim 90 \%$ of branched PEI amines and effectively all the PLL amines are protonated. The total number of charges per polymer can thus be determined by multiplying through by the $\mathrm{DP}_{\mathrm{w}}$. This correlates with the observation that branched PEI

Table 1

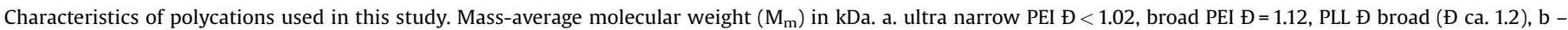

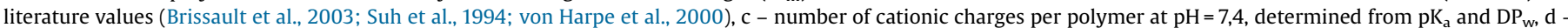
suppliers values.

\begin{tabular}{|c|c|c|c|c|c|}
\hline Name & Structure $^{a}$ & $\mathrm{M}_{\mathrm{m}}$ & $\mathrm{DP}_{\mathrm{w}}$ & $\mathrm{pK}_{\mathrm{a}}^{\mathrm{b}}$ & $\#+$ charges/polymer ${ }^{\mathrm{c}}$ \\
\hline PEI34 & narrow linear PEI.HCl & 1.3 & 34 & 7.45 & 19 \\
\hline PEI65 & narrow linear PEI.HCl & 2.8 & 65 & 7.45 & 36 \\
\hline PEI136 & narrow linear PEI.HCl & 5.9 & 136 & 7.45 & 75 \\
\hline PEI222 & narrow linear PEI.HCl & 9.8 & 222 & 7.45 & 122 \\
\hline PEI358 & narrow linear PEI.HCl & 15.9 & 358 & 7.45 & 197 \\
\hline PEI500 & broad linear PEI.HCl & 22.0 & 500 & 7.45 & 275 \\
\hline PLL4 & linear PLL.HBr & $0.8^{\mathrm{d}}$ & 4 & 10.5 & 4 \\
\hline PLL71 & linear PLL.HBr & $15.0^{\mathrm{d}}$ & 71 & 10.5 & 71 \\
\hline PLL115 & linear PLL.HBr & $24.0^{\mathrm{d}}$ & 115 & 10.5 & 115 \\
\hline PLL327 & linear PLL.HBr & $68.6^{\mathrm{d}}$ & 327 & 10.5 & 327 \\
\hline b-PEI & broad hyperbranched PEI freebase & $25.0^{\mathrm{d}}$ & 580 & 8.4 & 522 \\
\hline b-PEI.HCl & broad hyperbranched PEI. $\mathrm{HCl}$ & $25.0^{\mathrm{d}}$ & 580 & 8.4 & 522 \\
\hline
\end{tabular}


complexes DNA to a greater extent than linear PEI, due to the higher charge density of b-PEI. (Itaka et al., 2004) The number of protonated amines per polymer is shown in Table 1.

\subsection{Effect of polycations' molecular weight on membrane integrity and cell viability}

To determine whether polycations induced cell membrane disruption an LDH release assay was employed, which since it uses the supernatant only was multiplexed with an MTT assay by washing the cells in the culture well and supplying fresh media (see experimental 3.3). This assay measures the quantity of a cytosolic enzyme released from the cell, which is proportional to cell membrane disruption. This assay therefore reports the formation of permanent pores, but not transitory ones. LDH release experiments in previous reports showed qualitatively that polycations induce cell membrane damage. (Fischer et al., 2003; Ryser, 1967) By using well defined polymers of different molecular weights it will be possible to detect trends and thus provide quantitative data. The polymers were assayed by LDH release. After a $4 \mathrm{~h}$ exposure of the cells to the polycations the LDH release was assessed and the results are shown in Fig. 1.

Due to the relatively low toxicity of the smallest PEI cells were incubated with polymers for the $48 \mathrm{~h}$ and an LDH assay performed (Fig. 2). This exposure showed high levels of LDH release for all polycations at the $10 \mu \mathrm{g} / \mathrm{mL}$ concentration except PEI34 and PLL4. There is a drop in LDH "release" at the highest concentration due potentially to degradation of the released LDH. The data thus indicates that long-term exposure of cells with any PEI or PLL of significant molecular weight would be toxic.

To compare the toxicity data, the $4 \mathrm{~h}$ results were converted to semi-logarithmic dose-response curves and the line of best fit was converted into an $\mathrm{IC}_{20}$ and $\mathrm{IC}_{50}$ value by substitution of a linear data fit with 95\% confidence intervals (Table 2). In the case of the low MW 1-PEI it was concluded that $\mathrm{IC}_{20}$ and $\mathrm{IC}_{50}$ were much greater than $1000 \mu \mathrm{g} / \mathrm{mL}$.

PLL has been previously shown to lyse cell membranes(Hill et al., 1999) and has been reported to be more disruptive than l-PEI (Oku et al., 1986). Our current results confirmed this observation.
Comparing, for example, PEI358 and PLL327, which have similar number of repeat units, for the $4 \mathrm{~h}$ exposure experiment the PEI358 showed an $\mathrm{IC}_{20} 4.6$ times greater to PLL327, and an $\mathrm{IC}_{50}$ for the PEI that was above our measured range, whereas the $\mathrm{IC}_{50}$ of the PLL was low. This indicated that the order of toxicity was PLL $>$ b-PEI $>1-$ PEI. This is in agreement with the charge density of the polymers, with the most charge dense polymers being the most toxic.

Mitochondrial activity was assayed by the MTT assay using A549 lung cancer cells. Multiple exposure times (4, 24 and $48 \mathrm{~h}$ ) of the various polymers were undertaken (multiplexed with $\mathrm{LDH}$ ) and the cells seeded at 10,000 cells/well $16 \mathrm{~h}$ before experimentation. At the lower exposure times there was consistently greater mitochondrial activity in all experimental wells than the negative control well, except when extremely high concentrations were used, which led to immediate cell death. This is an observed phenomenon, but is rarely commented upon. Problems with increased mitochondrial activity during MTT are known(Stockert et al., 2012), and Parhamifar et al. suggest extreme caution is required when using MTT for just this reason(Parhamifar et al., 2010). A common explanation is mitochondrial uncoupling due to pore formation, but evidence relies on isolated mitochondria, and not whole cells(Grandinetti et al., 2011; Larsen et al., 2012). A simpler explanation could be that since polycations damage cell membranes, the cell is simply attempting to maintain homeostatis after sub-lethal damage, by upregulating respiration to provide energy to repair the damage.

With $4 \mathrm{~h}$ incubation with polycations (seeded at 10,000 cells/ well) the MTT assay showed the results presented in Fig. 3a. Experimental groups can be divided into a few that have suffered acute necrotic toxicity (the highest doses of the high MW polymers observed to disrupt cell membranes), and the majority which show mitochondrial activity values in excess of $100 \%$, with the least toxic (by LDH) polymers showing an inverse relationship to that expected - higher exposure concentrations provoked greater mitochondrial activity. The trend continued at 24 and $48 \mathrm{~h}$ (Figs. 3b and 3c), although it was less pronounced and at $48 \mathrm{~h}$ exposure with few experimental groups having greater than $100 \%$ mitochondrial activity. $\mathrm{IC}_{20} / \mathrm{IC}_{50}$ values are estimated in Table 3 in analogous fashion to Table 2 .

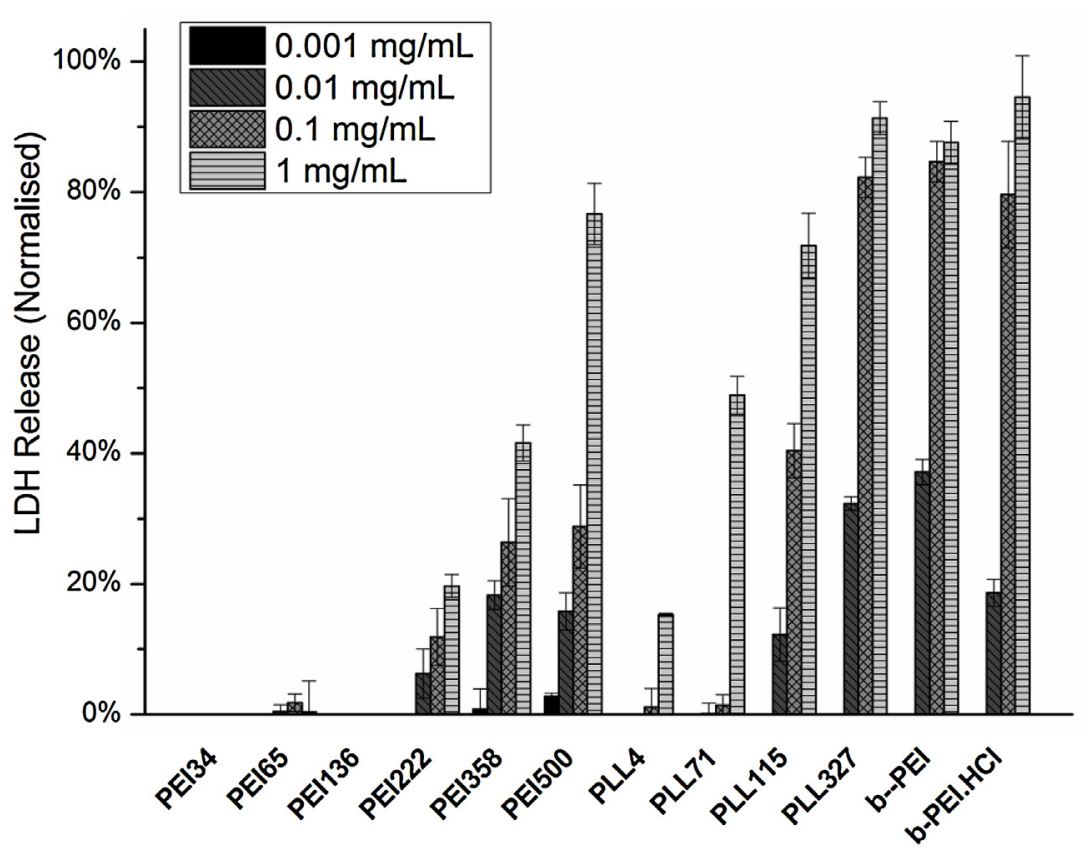

Fig. 1. LDH release assay on A549 cells after 4 h exposure. $n=4 \pm$ SD. Polymers information is provided at Table 1 . 


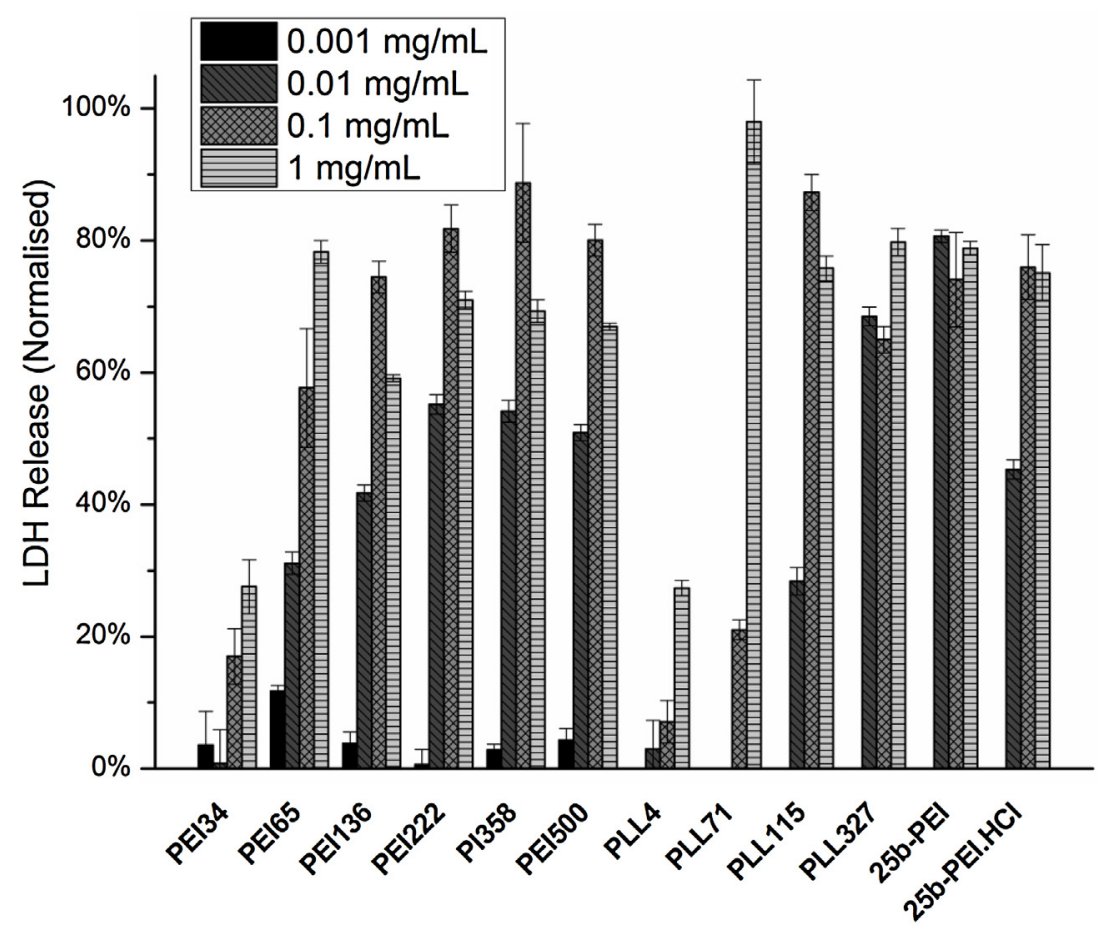

Fig. 2. LDH release assay on $A 549$ cells after $48 \mathrm{~h}$ exposure, $\mathrm{n}=4 \pm \mathrm{SD}$.

Table 2

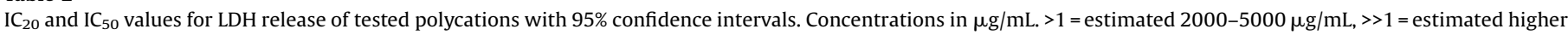
than $5000 \mu \mathrm{g} / \mathrm{mL}$

\begin{tabular}{|c|c|c|c|c|}
\hline \multirow[t]{2}{*}{ Material } & \multicolumn{2}{|l|}{ LDH $4 \mathrm{~h}$} & \multicolumn{2}{|l|}{$\mathrm{LDH} 48 \mathrm{~h}$} \\
\hline & $\mathrm{IC}_{20}(95 \% \mathrm{CI})$ & $\mathrm{IC}_{50}(95 \% \mathrm{CI})$ & $\mathrm{IC}_{20}(95 \% \mathrm{CI})$ & $\mathrm{IC}_{50}(95 \% \mathrm{CI})$ \\
\hline PEI34 & >> 1000 & >> 1000 & $173.5(83.7-359.6)$ & >> 1000 \\
\hline PEI65 & $>>1000$ & $>>1000$ & $2.6(2.3-2.9)$ & $54.2(48.6-60.4)$ \\
\hline PEI136 & >> 1000 & $>>1000$ & $4.1(1.5-10.9)$ & $48.6(18.3-129.2)$ \\
\hline PEI222 & 1209 (1085-1347) & >> 1000 & $3.3(1.3-8.6)$ & $27.2(10.5-70.8)$ \\
\hline PEI358 & $23.3(18.3-29.5)$ & >> 1000 & $3.4(1.2-9.5)$ & $24.6(8.7-69.6)$ \\
\hline PEI500 & $12.2(6.5-22.7)$ & $163.9(88.0-305.4)$ & $3.1(1.2-8.1)$ & $30.3(11.6-79.6)$ \\
\hline PLL4 & >> 1000 & >> 1000 & $362.4(204.6-641.9)$ & >> 1000 \\
\hline PLL71 & $65.8(21.8-198.4)$ & $1215(402.8-3665)$ & $21.3(8.5-53.4)$ & $103.9(41.5-260.0)$ \\
\hline PLL115 & $13.0(10.3-16.6)$ & $183.6(144.3-233.7)$ & $6.2(2.9-13.3)$ & $40.0(18.7-85.6)$ \\
\hline PLL327 & $4.5(2.9-7.0)$ & $31.1(20.2-47.8)$ & $4.3(1.6-11.5)$ & $28.5(10.6-76.9)$ \\
\hline 25b-PEI & $4.1(2.4-7.0)$ & $28.9(16.9-49.5)$ & $3.9(1.2-12.9)$ & $20.6(6.3-67.2)$ \\
\hline 25b-PEI.HCl & $6.3(4.2-9.5)$ & $38.5(25.3-58.4)$ & $5.9(2.8-12.4)$ & $41.4(19.6-87.1)$ \\
\hline
\end{tabular}

The $4 \mathrm{~h}$ exposure of cells to polycations and the assessed LDH and MTT are plotted against each other in Fig. S4. Ideally, if the two assays are complementary there should be a correlation. In our case this was indeed observed, showing complementarity of the two assays (Fig. S4). This suggests that the major cause of toxicity is the disruption of cellular membranes. The fact that mitochondrial activity is preserved even with very significant (ca. 30\%) LDH release shows that the cells can survive with major cell membrane damage when exposure to polycations is for short periods of time.

Cells were microscopically investigated, and micrographs of cells exposed to polycations for $48 \mathrm{~h}$ at $10 \mu \mathrm{g} / \mathrm{mL}$ are shown in Fig. 4. The control wells (Fig. 4a) show the typical morphology of A549 cells. With exposure to low MW polycations (PEI65) some squibs and cell debris are visible, but cells show generally healthy morphologies (Fig. 4b). As MW of polycation increases e.g. for PEI136 treatments the cells become rounded and lysed cells are visible (Fig. 4c), further increases to PEI222 shows the majority of cells dead (Fig. 4d), and at higher MW (PEI500) the vast majority of cells are lysed (Fig. 4e). PLL shows the same pattern (PLL327 shown in Fig. 4f). The same squib like cell debris was observed within 30 min by Martinez et al. with $10 \mathrm{mM}$ poly(allylamine hydrochloride). (Martinez et al., 2011) Since observations of these squibs have been made with PEI (both linear and branched), PLL and PAA it seems likely that this is a general feature of polycationic disruption of cell membranes. These squibs have also recently been observed for a variety of low molecular weight cationic amphiphiles(Casey, 2011).

This data shows that even relatively small polycations, such as PEI65 and PLL71 can induce cytotoxicity in the long term, even if minimal toxicity is observed during a $4 \mathrm{~h}$ exposure (typical for a transfection experiment). Only the extremely low molecular weight materials (PEI34,PLL4 and PLL71) were well tolerated for $48 \mathrm{~h}$, producing less than $25 \% \mathrm{LDH}$ release, although excess LDH release was still observed (Fig. 2), and an apparent increase in mitochondrial activity (Fig. 3c) showed that the cells were being stressed. Some cell debris was visible with PEI34 indicating that the membrane was being disrupted, but the cells were able to repair themselves. 


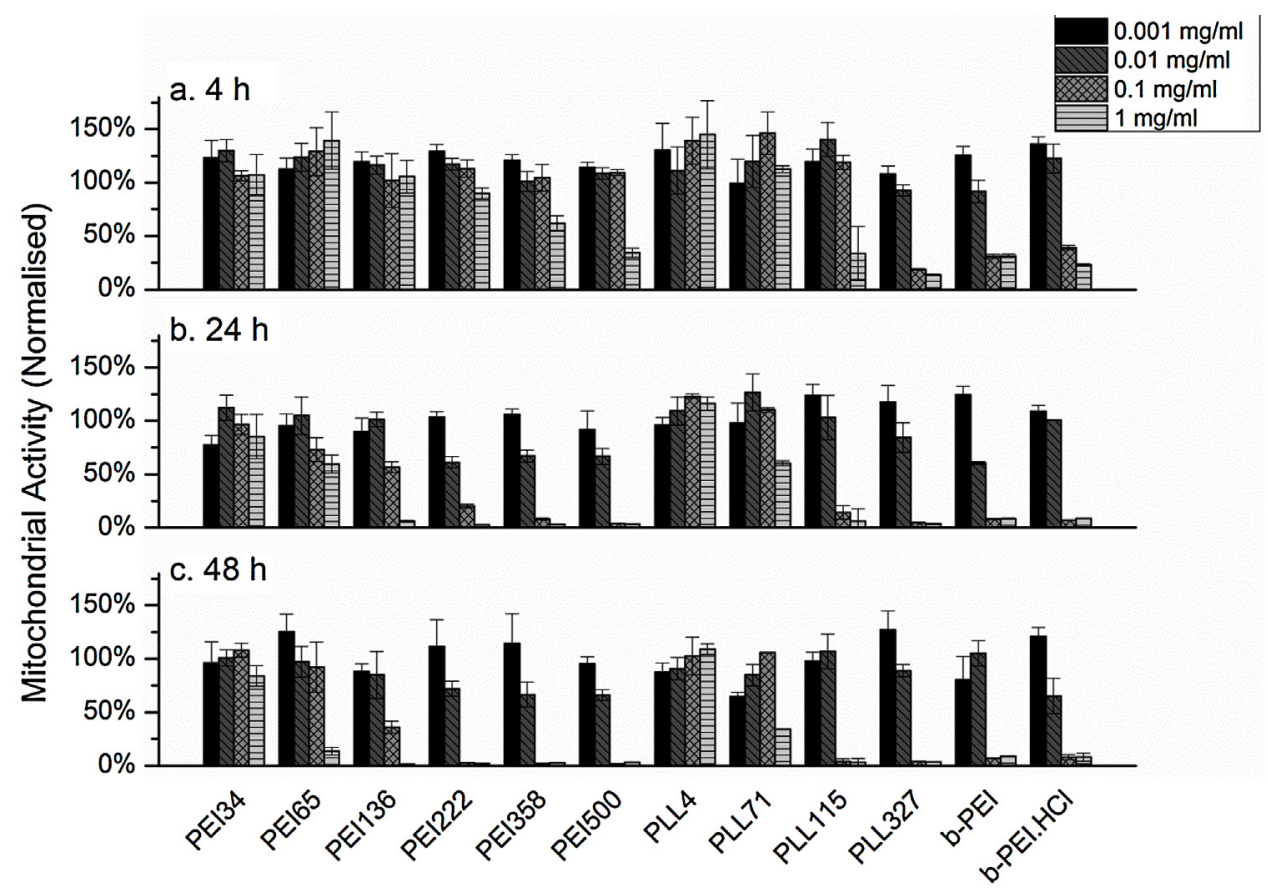

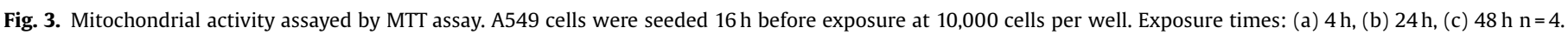

Table 3

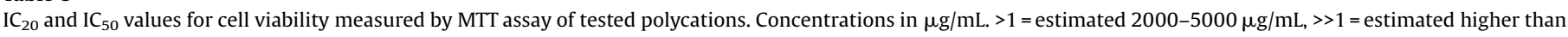
$5000 \mu \mathrm{g} / \mathrm{mL}$.

\begin{tabular}{|c|c|c|c|c|c|c|}
\hline \multirow[t]{2}{*}{ Material } & \multicolumn{2}{|l|}{ MTT $4 \mathrm{~h}$} & \multicolumn{2}{|l|}{ MTT $24 \mathrm{~h}$} & \multicolumn{2}{|l|}{ MTT $48 \mathrm{~h}$} \\
\hline & $\mathrm{IC}_{20}(95 \% \mathrm{CI})$ & $\mathrm{IC}_{50}(95 \% \mathrm{CI})$ & $\mathrm{IC}_{20}(95 \% \mathrm{CI})$ & $\mathrm{IC}_{50}(95 \% \mathrm{CI})$ & $\mathrm{IC}_{20}(95 \% \mathrm{CI})$ & $\mathrm{IC}_{50}(95 \% \mathrm{CI})$ \\
\hline PEI34 & $>>1000$ & $>>1000$ & $>>1000$ & $>>1000$ & $>>1000$ & >> 1000 \\
\hline PEI65 & $>1000$ & $>1000$ & 47.5 (19.3-116.7) & $2036(828.6-5000)$ & $35.5(17.1-73.6)$ & $195.7(94.3-406.2)$ \\
\hline PEI136 & >> 1000 & $>1000$ & $11.4(5.1-25.6)$ & $73.6(32.7-165.5)$ & $4.9(2.9-8.2)$ & $37.7(22.2-63.8)$ \\
\hline PEI222 & >> 1000 & >> 1000 & $3.7(2.7-5.0)$ & $25.8(19.0-35.0)$ & $5.7(3.2-10.0)$ & $27.2(15.4-48.0)$ \\
\hline PEI358 & $193.0(85.7-0.435)$ & $>>1000$ & $4.5(2.7-7.3)$ & $25.3(15.3-41.8)$ & $5.6(3.1-10.0)$ & $26.4(14.7-47.4)$ \\
\hline PEI500 & $66.1(22.6-193.6)$ & $433.7(148.2-1270)$ & $2.8(1.6-5.1)$ & $18.5(10.2-33.5)$ & $3.2(1.7-5.8)$ & $19.1(10.4-35.2)$ \\
\hline PLL4 & $>>1000$ & $>1000$ & $>>1000$ & >> 1000 & $>1000$ & $>>1000$ \\
\hline PLL71 & $95.0(29.0-310.6)$ & $397.5(121.6-1300)$ & $101.6(23.3-441.5)$ & $655.7(150.9-2849)$ & $25.2(4.4-142.9)$ & $61.0(10.8-346.2)$ \\
\hline PLL115 & $9.2(5.0-17.2)$ & $51.2(27.5-95.4)$ & $13.6(7.5-24.5)$ & $55.0(30.4-100.0)$ & $9.2(3.8-22.3)$ & $36.1(14.9-87.3)$ \\
\hline PLL327 & $2.4(0.4-12.5)$ & $<1$ & $8.3(4.6-14.9)$ & $35.8(19.8-65.6)$ & $10.6(5.9-19.1)$ & $41.1(22.8-74.1)$ \\
\hline 25b-PEI & $17.3(9.6-31.2)$ & $105.8(58.8-190.4)$ & $7.1(3.8-13.4)$ & $32.4(17.1-61.1)$ & $7.6(2.6-22.3)$ & $32.1(11.0-94.2)$ \\
\hline 25b-PEI.HCl & $32.0(18.3-56.2)$ & $141.0(80.3-247.4)$ & $10.1(4.7-21.7)$ & $42.8(20.0-91.8)$ & $6.8(3.8-12.4)$ & $32.5(17.9-59.1)$ \\
\hline
\end{tabular}

\subsection{Hydrolysis of phospholipids by l-PEI}

A study was conducted to assess Baciu et al.'s claim that PEI hydrolyses phospholipids, with the acidic proton being the protonated amine (Baciu et al., 2006). Control experiments showed no hydrolysis of DOPC by pure water at $37^{\circ} \mathrm{C}$ over a week. At $37^{\circ} \mathrm{C}$ PEI358 (which should be optimal for transfection) was mixed with DOPC at a ratio of 9.9 amines per DOPC (calculated to be the approximate ratio in a tissue culture well during transfection experiments). Hydrolysis was rapid, and apparently zero-order with respect to both reactants, and at the four $\mathrm{h}$ time point almost half of the DOPC had been hydrolysed (Fig. 5). Initial experiments incubating a wide range of different MW PEI in identical conditions (Fig. S5) suggest a molecular weight effect, which will be the subject of further investigation.

\subsection{Suggested mechanism of poration}

There is a strong molar mass effect on the destruction of cellular membranes and the cells release blebs possibly without caspase upregulation. DOPC liposomes are hydrolysed by PEI, apparently in a molar mass related manner (Fig. S5), Baciu et al.'s hydrolysis theory appears supported by the available evidence. The issue of toxicity resolves into whether membrane hydrolysis is occurring more rapidly than the cells repair systems, or not. When hydrolysis is more rapid than repair this leads to eventual cell death by lysis of the membrane. If the rate of repair can counterbalance the lysis of membranes the material is tolerated with an observable increase in mitochondrial activity to power the repair.

We have previously suggested that hydrolysis can be used to explain endosomal release without resorting to hydrostatic pressure. (Monnery and Hoogenboom, 2015) In short the polycation-polyanion complex will fall apart when acidified if the $\mathrm{pK}_{\mathrm{a}}$ of the polycation is within the normal range of cells, and the released free polycations will subsequently hydrolyse the phospholipids to induce a pore in the endosome from within. It also raises a potential mechanism for internalization without endocytosis, and release via autophagy. 


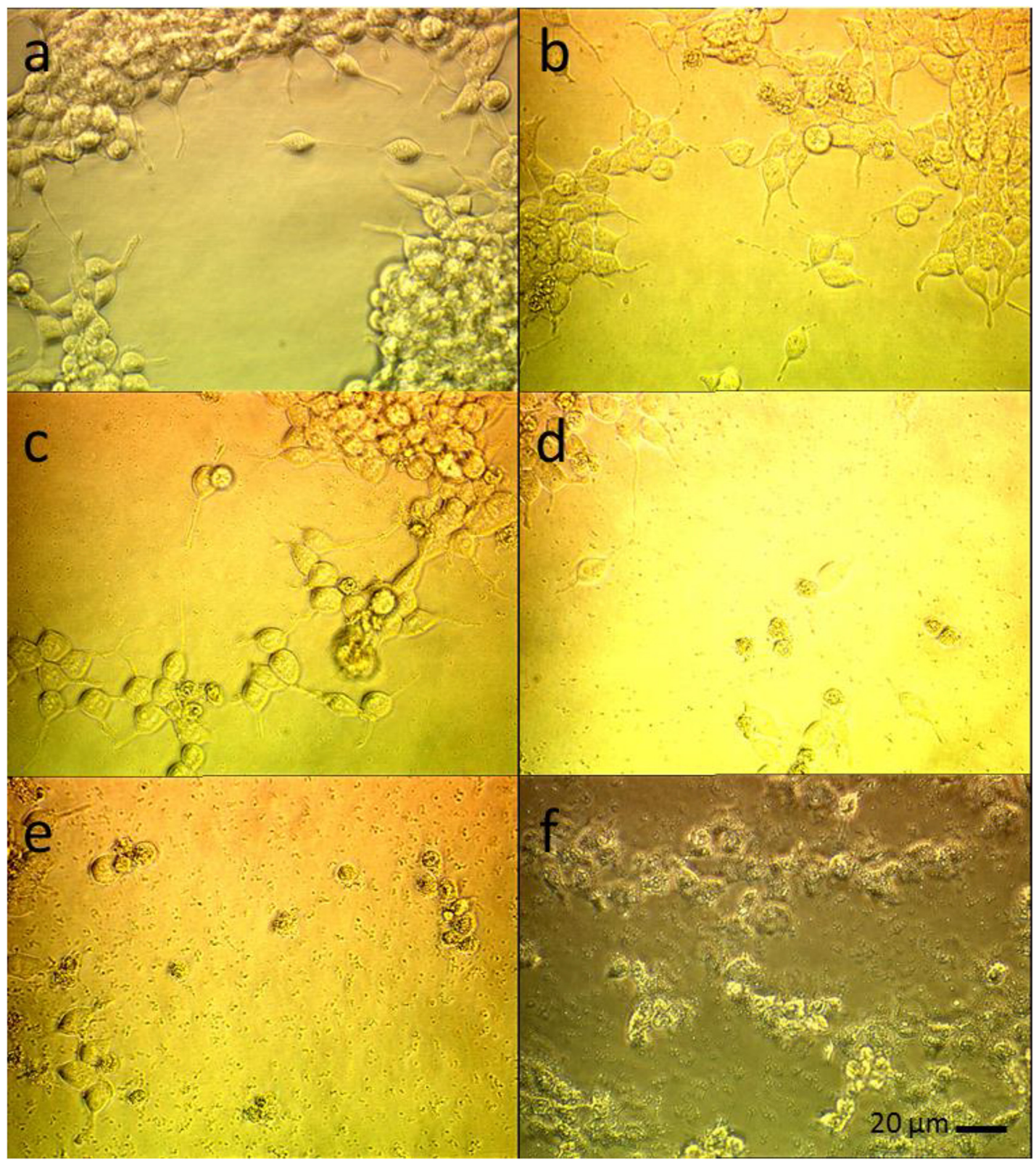

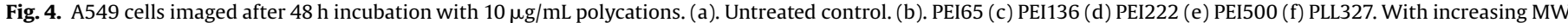
cells start shedding vesicles, rounding up and finally lysing. PLL shows the same morphologies.

\section{Conclusions}

We set out to determine the relationship between the molecular weight of 1-PEI (and related polycations) and cytotoxicity, a topic of much speculation but no unambiguous data to date. Assays of cell membrane damage and mitochondrial activity clearly showed a dose-response and importantly a molecular weight response. We have concluded that the cytotoxicity of polycations is directly related to molecular weight and $\mathrm{pK}_{\mathrm{a}}$, with higher molecular weight and more cationic materials being more toxic. The disruption of cell membranes even by low MW polycations over time indicates there is no such thing as "nontoxic" polycations. Two theories of the mechanism of cellular membranes (hydrolysis and surfactant-effect) have been proposed in the literature, and our observations of cells and liposomes support the hydrolysis theory as first toxicity effect on the cell, as the predicted blebs are observed with cells and DOPC hydrolyses to MOPC and oleic acid in the presence of 1-PEI dependent on the molecular weight of the polymer. The mechanism of toxicity appears, thus, to have as first step the hydrolysis of cellular phospholipids. This has implications on polymeric transfection and could provide a potential mechanism of cellular entry without endocytosis.

\section{Author contributions}

The manuscript was written through contributions of all authors. All authors have given approval to the final version of the manuscript.

\section{Acknowledgements}

This work was supported by the UK Engineering and Physical Sciences Research Council via the Institute of Chemical Biology, Imperial College London. 


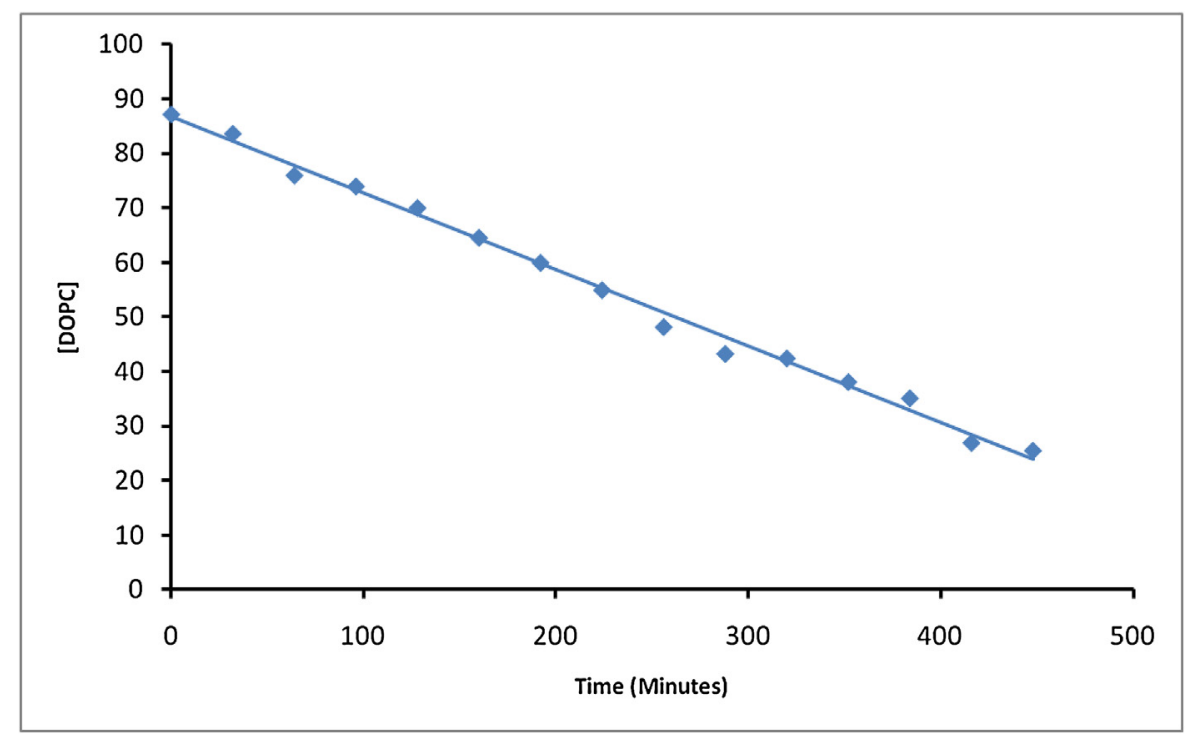

Fig. 5. Concentration (in $\mu \mathrm{g} / \mathrm{mL}$ ) of DOPC during hydrolysis with l-PEI358 at $37^{\circ} \mathrm{C}$.

\section{Appendix A. Supplementary data}

Supplementary data associated with this article can be found, in the online version, at http://dx.doi.org/10.1016/j.ijpharm.2017. 02.048.

\section{References}

Adib, A., Stock, F., Erbacher, P., 2010. Method for Manufacturing Linear Polyethylenimine (PEI) for Transfection Purpose and Linear PEI Obtained with Such Method. (US Patent 2010/197888).

Baciu, M., Sebai, S.C., Ces, O., Mulet, X., Clarke, J.A., Shearman, G.C., Law, R.V., Templer, R.H., Plisson, C., Parker, C.A., Gee, A., 2006. Degradative transport of cationic amphiphilic drugs across phospholipid bilayers. Philos. Trans. R. Soc. A Math. Phys. Eng. Sci. 364, 2597-2614.

Behr, J.-P., 2012. Synthetic gene transfer vectors II: back to the future. Acc. Chem. Res. 45, 980-984.

Boe, S., Longva, A.S., Hovig, E., 2008. Evaluation of various polyethylenimine formulations for light-controlled gene silencing using small interfering RNA molecules. Oligonucleotides 18 (2), 123-132.

Boeckle, S., Gersdorff, K.V., Piepen, S.V.D., Culmsee, C., Wagner, E., Ogris, M., 2004. Purification of polyethylenimine polyplexes highlights the role of free polycations in gene transfer. J. Gene Med. 6, 1102-1111.

Brissault, B., Kichler, A., Guis, C., Leborgne, C., Danos, O., Cheradame, H., 2003. Synthesis of linear polyethylenimine derivatives for DNA transfection. Bioconjugate Chem. 14, 581-587.

Casey, D., Charalambous, K., Gee, A., Law, R.V., Ces, O., 2014. Amphiphilic drug interactions with model cellular membranes are influenced by lipid chainmelting temperature. J. R. Soc. Interface 11.

Casey, D.R., 2011. Drug interactions with lipid membranes: the effects of drug and lipid structure upon rates of ester hydrolysis, unpublished Ph.D. Thesis. Imperial College, London.

Dai, Z., Gjetting, T., Mattebjerg, M.A., Wu, C., Andresen, T.L., 2011. Elucidating the interplay between DNA-condensing and free polycations in gene transfection through a mechanistic study of linear and branched PEI. Biomaterials 32, 86268634.

de la Rosa, V.R., Bauwens, E., Monnery, B.D., De Geest, B.G., Hoogenboom, R., 2014. Fast and accurate partial hydrolysis of poly(2-ethyl-2-oxazoline) into tailored linear polyethylenimine copolymers. Polym. Chem. 5, 4957-4964.

Eberhardy, S., Radzniak, L., Liu, Z., 2009. Iron (III) citrate inhibits polyethyleniminemediated transient transfection of Chinese hamster ovary cells in serum-free medium. Cytotechnology 60, 1-9.

Fahrmeir, J., Gunther, M., Tietze, N., Wagner, E., Ogris, M., 2007. Electrophoretic purification of tumor-targeted polyethylenimine-based polyplexes reduces toxic side effects in vivo. J. Controlled Release 122, 236-245.

Falco, A., Encinas, P., Carbajosa, S., Cuesta, A., Chaves-Pozo, E., Tafalla, C., Estepa, A., Coll, J.M., 2009. Transfection improvements of fish cell lines by using deacylated polyethylenimine of selected molecular weights. Fish Shellfish Immunol. 26, 559-566.

Fasman, G.D., Idelson, M., Blout, E.R., 1961. The synthesis and conformation of high molecular weight poly- $\varepsilon$-carbobenzyloxy-l-lysine and poly-l-lysine $\cdot \mathrm{HCl} 1,2$. J. Am. Chem. Soc. 83, 709-712.
Fischer, D., Li, Y., Ahlemeyer, B., Krieglstein, J., Kissel, T., 2003. In vitro cytotoxicity testing of polycations: influence of polymer structure on cell viability and hemolysis. Biomaterials 24, 1121-1131.

Frey, B.L., Corn, R.M., 1996. Covalent attachment and derivatization of poly(l-lysine) monolayers on gold surfaces As characterized by polarization-modulation FT-IR spectroscopy. Anal. Chem. 68, 3187-3193.

Shearman, G.C., Attard, G.S., Hunt, A.N., Jackowski, S., Baciu, M., Sebai, S.C., Mulet, X., Clarke, J.A., Law, R.V., Plisson, C., Parker, C.A., Gee, A., Ces, O., Templer, R.H., 2007. Using membrane stress to our advantage. Biochem. Soc. Trans. 498-501.

Gary, D.J., Puri, N., Won, Y.-Y., 2007. Polymer-based siRNA delivery: perspectives on the fundamental and phenomenological distinctions from polymer-based DNA delivery. J. Controlled Release 121, 64-73.

Grandinetti, G., Ingle, N.P., Reineke, T.M., 2011. Interaction of poly(ethylenimine)DNA polyplexes with mitochondria: implications for a mechanism of cytotoxicity. Mol. Pharm. 8, 1709-1719.

Grandinetti, G., Smith, A.E., Reineke, T.M., 2012. Membrane and nuclear permeabilization by polymeric pDNA vehicles: efficient method for gene delivery or mechanism of cytotoxicity? Mol. Pharm. 9, 523-538.

Hanzlikova, M., Ruponen, M., Galli, E., Raasmaja, A., Aseyev, V., Tenhu, H., Urtti, A., Yliperttula, M., 2011. Mechanisms of polyethylenimine-mediated DNA delivery: free carrier helps to overcome the barrier of cell-surface glycosaminoglycans. J. Gene Med. 13, 402-409.

Hapala, I., 1997. Breaking the barrier: methods for reversible permeabilization of cellular membranes. Crit. Rev. Biotechnol. 17, 105-122.

Hill, I.R.C., Garnett, M.C., Bignotti, F., Davis, S.S., 1999. In vitro cytotoxicity of poly (amidoamine)s: relevance to DNA delivery. Biochim. Biophys. Acta (BBA) - Gen. Subj. 1427, 161-174.

Hong, S., Bielinska, A.U., Mecke, A., Keszler, B., Beals, J.L., Shi, X., Balogh, L., Orr, B.G., Baker, J.R., Banaszak Holl, M.M., 2004. Interaction of poly(amidoamine) dendrimers with supported lipid bilayers and cells: hole formation and the relation to transport. Bioconjugate Chem. 15, 774-782.

Hong, S., Leroueil, P.R., Janus, E.K., Peters, J.L., Kober, M.-M., Islam, M.T., Orr, B.G., Baker, J.R., Banaszak Holl, M.M., 2006. Interaction of polycationic polymers with supported lipid bilayers and cells: nanoscale hole formation and enhanced membrane permeability. Bioconjugate Chem. 17, 728-734.

Itaka, K., Harada, A., Yamasaki, Y., Nakamura, K., Kawaguchi, H., Kataoka, K., 2004. In situ single cell observation by fluorescence resonance energy transfer reveals fast intra-cytoplasmic delivery and easy release of plasmid DNA complexed with linear polyethylenimine. J. Gene Med. 6, 76-84.

Kadlecova, Z., Nallet, S., Hacker, D.L., Baldi, L., Klok, H.-A., Wurm, F.M., 2012. Poly (ethyleneimine)-mediated large-scale transient gene expression: influence of molecular weight, polydispersity and N-propionyl groups. Macromol. Biosci. 12, 628-636.

Kichler, A., Leborgne, C., Coeytaux, E., Danos, O., 2001. Polyethylenimine-mediated gene delivery: a mechanistic study. J. Gene Med. 3, 135-144.

Lambermont-Thijs, H.M.L., van der Woerdt, F.S., Baumgaertel, A., Bonami, L., Du Prez, F.E., Schubert, U.S., Hoogenboom, R., 2009. Linear poly(ethylene imine)s by acidic hydrolysis of poly(2-oxazoline)s: kinetic screening, thermal properties, and temperature-induced solubility transitions. Macromolecules 43, 927-933.

Larsen, A.K., Malinska, D., Koszela-Piotrowska, I., Parhamifar, L., Hunter, A.C. Moghimi, S.M., 2012. Polyethylenimine-mediated impairment of mitochondrial membrane potential, respiration and membrane integrity: implications for nucleic acid delivery and gene therapy. Mitochondrion 12, 162-168.

Layman, J.M., Ramirez, S.M., Green, M.D., Long, T.E., 2009. Influence of polycation molecular weight on poly(2-dimethylaminoethyl methacrylate)-mediated DNA delivery In vitro. Biomacromolecules 10, 1244-1252. 
Leroueil, P.R., Berry, S.A., Duthie, K., Han, G., Rotello, V.M., McNerny, D.Q., Baker, J.R. Orr, B.G., Banaszak-Holl, M.M., 2008. Wide varieties of cationic nanoparticles induce defects in supported lipid bilayers. Nano Lett. 8, 420-424.

Litt, M., Levy, A., Herz, J., 1975. Polymerization of cyclic imino ethers. X. Kinetics, chain transfer, and repolymerization. J. Macromol. Sci.: Part A - Chem. 9, 703727.

Martinez, J.S., Keller, T.C.S., Schlenoff, J.B., 2011. Cytotoxicity of free versus multilayered polyelectrolytes. Biomacromolecules 12, 4063-4070.

Mecke, A., Majoros I. n.J. Patri, A.K., Baker, J.R., Banaszak Holl, M.M., Orr, B.G., 2005 Lipid bilayer disruption by polycationic polymers: the roles of size and chemical functional group. Langmuir 21, 10348-10354.

Moghimi, S.M., Symonds, P., Murray, J.C., Hunter, A.C., Debska, G., Szewczyk, A., 2005. A two-stage poly(ethylenimine)-mediated cytotoxicity: implications for gene transfer/therapy. Mol. Ther. 11, 990-995.

Monnery, B.D., Hoogenboom, R., 2015. Synthesis and properties of polyalkylenimines, cationic polymers in regenerative medicine. R. Soc. Chem. 30-61.

Monnery, B.D., Shaunak, S., Thanou, M., Steinke, J.H.G., 2015. Improved synthesis of linear poly(ethylenimine) via low-temperature polymerization of 2-Isopropyl2-oxazoline in chlorobenzene. Macromolecules 48, 3197-3206.

Oku, N., Yamaguchi, N., Yamaguchi, N., Shibamoto, S., Ito, F., Nango, M., 1986. The fusogenic effect of synthetic polycations on negatively charged lipid bilayers. J. Biochem. (Tokyo) 100, 935-944.

Pack, D.W., Hoffman, A.S., Pun, S., Stayton, P.S., 2005. Design and development of polymers for gene delivery. Nat. Rev. Drug Discov. 4, 581-593.

Parhamifar, L., Larsen, A.K., Hunter, A.C., Andresen, T.L., Moghimi, S.M., 2010. Polycation cytotoxicity: a delicate matter for nucleic acid therapy-focus on polyethylenimine. Soft Matter 6, 4001-4009.
Rivas, B.L., Ananías, S.I., 1987. Ring opening polymerization of 2-ethyl-2-oxazoline. Polym. Bull. 18, 189-194.

Ryser, H.J.-P., 1967. A membrane effect of basic polymers dependent on molecular size. Nature 215, 934-936.

Saegusa, T., Ikeda, H., Fujii, H., 1972. Crystalline polyethylenimine. Macromolecules 5 108-108.

Seddon, A.M., Casey, D., Law, R.V., Gee, A., Templer, R.H., Ces, O., 2009. Drug interactions with lipid membranes. Chem. Soc. Rev. 38, 2509-2519.

Shortt, D.W., 1994. Measurement of narrow-distribution polydispersity using multiangle light scattering. J. Chromatogr. A 686, 11-20.

Stockert, J.C., Blazquez-Castro, A Canete, M., Horobin, R.W., Villanueva, A., 2012 MTT assay for cell viability: intracellular localization of the formazan product is in lipid droplets. Acta Histochem. 114 (8), 785-796.

Suh, J., Paik, H.J., Hwang, B.K., 1994. Ionization of poly(ethylenimine) and poly (allylamine) at various pH's. Bioorg. Chem. 22, 318-327.

Vaidyanathan, S., Orr, B.G., Banaszak Holl, M.M., 2016. Role of cell membrane-vector interactions in successful gene delivery. Acc. Chem. Res. 49, 1486-1493.

von Harpe, A., Petersen, H., Li, Y., Kissel, T., 2000. Characterization of commercially available and synthesized polyethylenimines for gene delivery. J. Controlled Release 69, 309-322.

Warakomski, J.M., Thill, B.P., 1990. Evidence for long chain branching in polyethyloxazoline. J. Polym. Sci. A: Polym. Chem. 28, 3551-3563.

Yue, Y., Jin, F., Deng, R., Cai, J., Chen, Y., Lin, M.C.M., Kung, H.-F., Wu, C., 2011. Revisit complexation between DNA and polyethylenimine - Effect of uncomplexed chains free in the solution mixture on gene transfection. J. Controlled Release 155, 67-76. 